\title{
Degradation of Some Ceria Electrolytes Under Hydrogen Contact Nearby Anode in Solid Oxide Fuel Cells (SOFCs)
}

\author{
Luiz Fernando Brum Malta*, Tsuneharu Ogasawara* \\ UFRJ/COPPE PEMM, Bloco F sala F206B, CT/UFRJ \\ C.P. 68505, Ilha do Fundão, 21945-970, Brazil
}

Received: September 2, 2002; Revised: September 4, 2002

\begin{abstract}
This work is concerned with thermodynamic analysis of the stability of some ceria electrolytes under contact with hydrogen gas nearby anode in fuel cells. It was considered the following types of ceria-electrolytes: pure ceria, strontium-doped ceria, calcium-doped ceria and calciumbismuth-doped ceria. The equilibrium $\mathrm{Log}\left(\mathrm{pH}_{2} \mathrm{O} / \mathrm{pH} 2\right) v s$. T diagrams were constructed for $\mathrm{x}=0.1$ and 0.01 , where $\mathrm{x}$ is the fraction of initial ceria converted to $\mathrm{Ce}_{2} \mathrm{O}_{3}$ (proportional to the ratio between activities of $\mathrm{Ce}^{3+}$ and $\mathrm{Ce}^{4+}$ in the ceria electrolyte, which is proportional to the fraction of electronic conduction in the electrolyte at a given temperature). The predictions of the diagrams are as follows: (a) $\mathrm{Ce}_{1.9} \mathrm{Ca}_{0.1} \mathrm{Bi}_{0.8} \mathrm{O}_{5.1}$ and $\mathrm{Ce}_{0.9} \mathrm{Sr}_{0.1} \mathrm{O}_{1.9}$ are less stable than pure ceria for the whole temperature range (from 0 to $1000^{\circ} \mathrm{C}$ ); (b) $\mathrm{Ce}_{0.9} \mathrm{Ca}_{01} \mathrm{O}_{1.9}$ is more stable than pure ceria below about $650{ }^{\circ} \mathrm{C}$ for $\mathrm{x}=0.1$ and below about $400{ }^{\circ} \mathrm{C}$ for $\mathrm{x}=0.01$; (c) at each temperature in the considered range the pressure ratio $\mathrm{pH}_{2} \mathrm{O}(\mathrm{g}) / \mathrm{pH}_{2}(\mathrm{~g})$ has to be higher than thermodynamically predicted in order to keep $\mathrm{CeO}_{2}$ stable in the electrolyte contacting hydrogen gas. Thermodynamic predictions are entirely capable of explaining experimental data published on the subject (irreversible cell degradation in the case of SrO-doped ceria; weight loss from doped-ceria electrolyte above $700{ }^{\circ} \mathrm{C}$; oxygen gas release during sintering of ceria).
\end{abstract}

Keywords: ceria electrolytes, SOFCs, anode reaction, degradation of ceria

\section{Introduction}

Fuel cells are expected to become the best solution for electric energy generation and electrical-vehicle by electrochemical energy conversion from hydrocarbon fuels, because of the higher conversion efficiency and lesser pollution. In this sense, efforts are applied worldwide for direct fueling fuel cells with hydrocarbon by means of in situ catalytic reforming of the same. Allied to the poisoning of the catalysts, there problems concerned with the attack of the $\mathrm{CO}$ and $\mathrm{H}_{2}$ to the anode composite (e.g. nickel-solid oxide ) when the solid oxide electrolyte used is ceria. This kind of electrolyte deserves attention from the viewpoint of attempting to reduce high temperature corrosion problems to current collector/interconnectors when fuel cells are operated using zirconia electrolytes (operation temperature in the range of 900 to $1000^{\circ} \mathrm{C}$ ). Ceria electrolytes are designed to allow solid oxide fuel cells being successfully operated at lower temperatures $\left(500\right.$ to $\left.800{ }^{\circ} \mathrm{C}\right)$, without too much decrease in ionic conductivity (which means loss in electri- cal current density or power density). This work deals with the problem of ceria electrolyte in the anode region of the fuel cells being affected by the hydrogen gas action, thereby suffering from loss electrical efficiency due to electronic conduction as a result of the $\mathrm{Ce}^{4+}$ to $\mathrm{Ce}^{3+}$. More precisely, the behavior of ceria doped with $\mathrm{Ca}, \mathrm{Sr}$ and their mixture is focused.

Hydrothermal synthesis of nanocrystalline codoped cerias (particle size in the range $15 \mathrm{~nm}$ to $30 \mathrm{~nm}$ ) $\mathrm{Ce}_{1-\mathrm{x}} \mathrm{M}_{\mathrm{x}} \mathrm{Bi}_{0.4} \mathrm{O}_{2.6-\mathrm{x}}$ (where $\mathrm{M}=\mathrm{Ca}$, $\mathrm{Sr}$ e Ba; $0.01 \leq x \leq 0.15$ ) appeared promising as solid electrolyte for fuel cells operating in the 500 to $800{ }^{\circ} \mathrm{C}$ temperature range and the highest oxygen ion conductivity provided by

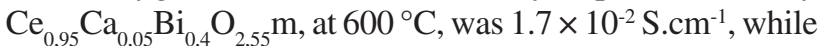
the maximum power density was $140 \mathrm{~mW} / \mathrm{cm}^{2}$ at $500{ }^{\circ} \mathrm{C}^{1}$. $\mathrm{Li}$ et al. $^{2}$ produced nanocrystalline $(\mathrm{CeO} 2)(1-\mathrm{x})(\mathrm{BiO} 1.5) \times$ ( $\mathrm{x}=0.0$ to 0.5$)$ under moderate hydrothermal conditions, $240{ }^{\circ} \mathrm{C}$; a fluorite type cubic structure ceria was achieved

*e-mail: brumalta@mealmat.ufrj.br; ogasawat@metalmat.ufrj.br Presented at the International Symposium on High Temperature Corrosion in Energy Related Systems, Angra dos Reis - RJ, September 2002. 
when $\mathrm{x}<0.5$. Doshi et al. ${ }^{3}$ showed that fuel cells based on doped ceria electrolyte may be operated at $500{ }^{\circ} \mathrm{C}$, but improvement in the technology to manufacture thin film electrolyte is still necessary in order to get open circuit voltage of 0.97 to $1 \mathrm{~V}$. Another problem concerned with the doped ceria electrolyte is its decomposition by hydrogen gas during high temperature operation, generating $\mathrm{Ce}_{2} \mathrm{O}_{3}$, which imposes power losses to the fuel cell due to electronic conduction ${ }^{4}$.

Cerias doped with rare earth metal oxides are also important options Sahibzada et al. ${ }^{5}$ incorporated a dense film (5 to $10 \mu \mathrm{m}$ ) of $\mathrm{Ce}_{0.9} \mathrm{Gd}_{0.1} \mathrm{O}_{0.95}$ by tape casting on Ni-YSZ anode substrate and investigated the behaviour of a hydrogen fuel cell in the temperature range from 550 to $650{ }^{\circ} \mathrm{C}$, using $\mathrm{La}_{0.6} \mathrm{Sr}_{0.4} \mathrm{Co}_{0.2} \mathrm{Fe}_{0.8} \mathrm{O}_{3}$ cathode, and obtained an open circuit voltage of 0.75 to $0.8 \mathrm{~V}$ as well as power of $125 \mathrm{~mW} /$ $\mathrm{cm}$ at $650{ }^{\circ} \mathrm{C}$ and $30 \mathrm{~mW} / \mathrm{cm}^{2}$ at $550{ }^{\circ} \mathrm{C}$; direct use of methanol in the anode was tested at $600{ }^{\circ} \mathrm{C}$.

Maffei \& Kuriakose ${ }^{6}$ made planar solid oxide fuel cells with doubly doped ceria (with Gd and Pr) and tested at $700{ }^{\circ} \mathrm{C}$. An argon $-4 \%$ hydrogen gas mixture was used at the anode while air was used at the cathode.

Besides considerable electronic conduction, the doubly doped ceria showed a chemical reduction by hydrogen above about $700{ }^{\circ} \mathrm{C}$.

Milliken, Guruswamy \& $\mathrm{Khandkar}^{7}$ obtained power densities $>250 \mathrm{~mW} / \mathrm{cm}^{2}$ at $700{ }^{\circ} \mathrm{C}$, with stable performance during $15000 \mathrm{~h}$, in individual fuel cells of samaria doped ceria electrolyte. Good efficiency of up to $42 \%$ was gotten when the fuel cell was operated with humid hydrogen.

Other studies on rare earth doped cerias were carried out by Murray, Tsai \& Barnett ${ }^{8}$, Maric et al. ${ }^{9}$, Uchida, Osuga \& Watanabe ${ }^{10}$, Marina et al. ${ }^{11}$, Ishihara et al. ${ }^{12}$, Uchida, Suzuki \& Watanabe ${ }^{13}$ and Antonucci et al ${ }^{14}$, among others, which point out the relevant role to be played by doped ceria in solid oxide fuel cells.

The Research Group of Ogasawara et al. ${ }^{15-18}$, at PEMM/ COPPE/UFRJ, is carrying out developments in fuel cells with doped ceria electrolytes, and already concluded that it is possible to hydrothermally synthesize $\mathrm{Ce}_{0,9} \mathrm{Ca}_{0,10} \mathrm{O}_{1,9}$ in autoclave at $220{ }^{\circ} \mathrm{C}$ for $4 \mathrm{~h}$, at $\mathrm{pH}$ in the range from 13 to 14 , and obtaining an electrolyte with ionic conductivity of $1.0 \times 10^{-3} \mathrm{~S} / \mathrm{cm}$ at $390{ }^{\circ} \mathrm{C}$.

The present work deals with the thermodynamic analysis of the Ce-Ca-Bi-O- $\mathrm{H}_{2}-\mathrm{H}_{2} \mathrm{O}(\mathrm{g})$ system by constructing diagrams of $\mathrm{pH}_{2} \mathrm{O} / \mathrm{pH}_{2} v s$. temperature and comparing their predictions with experimentally known features..

\section{Thermodynamic Data}

The thermodynamic data used in this study were found in the Main Database of the HSC Chemistry for Windows 4.1, from Outokumpu Oy (Finland), licensed to the Metal- lurgical and Materials Engineering Department of COPPE/ UFRJ. Those data referring to the key-species $\mathrm{Ce}_{1.9} \mathrm{Ca}_{0,1} \mathrm{Bi}_{0,8} \mathrm{O}_{5,1}, \mathrm{Ce}_{0,9} \mathrm{Ca}_{0,1} \mathrm{O}_{1,9}$ and $\mathrm{Ce}_{0,9} \mathrm{Sr}_{0,1} \mathrm{O}_{1,9}$, are displayed in Tables 1, 2 and 3, respectively.

\section{Calculation and Interpretation of the Diagrams}

The calculation was carried out by using the Chemical Reaction Module of the referred HSC Chemistry for Windows 4.1 Software, and the diagrams were mounted by hand. The important chemical reactions are the following:

$$
\begin{aligned}
& \mathrm{CeO}_{2}+0.5 \mathrm{H}_{2}(\mathrm{~g})=0.5 \mathrm{Ce}_{2} \mathrm{O}_{3}+0.5 \mathrm{H}_{2} \mathrm{O}(\mathrm{g}) \\
& \mathrm{Ce}_{0,9} \mathrm{Ca}_{0,1} \mathrm{O}_{1,9}+0.45 \mathrm{H}_{2}(\mathrm{~g})=0.45 \mathrm{Ce}_{2} \mathrm{O}_{3}+0.1 \mathrm{CaO}+0.45 \mathrm{H}_{2} \mathrm{O}(\mathrm{g})(3) \\
& \mathrm{Ce}_{0,9} \mathrm{Sr}_{0,1} \mathrm{O}_{1.9}+0.45 \mathrm{H}_{2}(\mathrm{~g})=0.45 \mathrm{Ce}_{2} \mathrm{O}_{3}+0.1 \mathrm{SrO}+0.45 \mathrm{H}_{2} \mathrm{O}(\mathrm{g}) \\
& \mathrm{Ce}_{1,9} \mathrm{Ca}_{0,1} \mathrm{Bi}_{0,8} \mathrm{O}_{5,1}+0.95 \mathrm{H}_{2}(\mathrm{~g})=0.85 \mathrm{Ce}_{2} \mathrm{O}_{3}+0.1 \mathrm{CaBi}_{2} \mathrm{O}_{4}+ \\
& 0.2 \mathrm{CeBi}_{3} \mathrm{O}_{6}+0.95 \mathrm{H}_{2} \mathrm{O}(\mathrm{g})
\end{aligned}
$$

It is defined $\mathrm{x}$ as the molar fraction of each doped ceria which decomposes under the action of the hydrogen gas. Consequently, (1- $\mathrm{x})$ is the molar fraction of the referred doped ceria which remains unaltered, while $\mathrm{Ce}_{2} \mathrm{O}_{3}$ is derived by the same decomposition.

\section{Presentation and Interpretation of the Diagrams}

Figure 1 shows the $\log \left(\mathrm{pH}_{2} \mathrm{O} / \mathrm{pH}_{2}\right)$ vs. temperature diagram of the cerias doped with calcia, strontia and calciabismuth oxide, for $x=0.1$. Below a particular curve it's located the stability domain of $\mathrm{Ce}^{3+}$ cation, that is, of $\mathrm{Ce}_{2} \mathrm{O}_{3}$; so, the stability domain of ceria $\left(\mathrm{CeO}_{2}\right.$, that is, of $\mathrm{Ce}^{4+}$ cation $)$ is located above the referred curve. Therefore, it may be observed that $\mathrm{Ce}_{0,9} \mathrm{Ca}_{0.1} \mathrm{O}_{1.9}$ is only unique doped ceria more stable than the pure ceria below $650{ }^{\circ} \mathrm{C}$.

Figure 2 shows the $\log \left(\mathrm{pH}_{2} \mathrm{O} / \mathrm{pH}_{2}\right)$ vs. temperature diagram for the same system in the case of $x=0.01$, which is notably more restrictive with respective to the maximum temperature of ceria stability under hydrogen than in the case of $\mathrm{x}=0.1$.

\section{Final Discussion}

It's worthwhile to note that these diagrams presented here are entirely new in the context of ceria electrolyte fuel cells.

The fraction of doped ceria which decomposes under action of hydrogen gas is directly proportional to the ratio $\left(\mathrm{a}_{\mathrm{Ce}} 3+/ \mathrm{a}_{\mathrm{Ce}} 4+\right)$ of the solid electrolyte. The cation $\mathrm{Ce}^{3+}$ is carrier of 1 electron in excess to that carried by the cation $\mathrm{Ce}^{4+}$ 
Table 1. Thermodynamic data of the species $\mathrm{Ce}_{1.9} \mathrm{Ca}_{0.1} \mathrm{Bi}_{0.8} \mathrm{O}_{5,1}$ : coefficients $\mathrm{A}, \mathrm{B}, \mathrm{C}$ and $\mathrm{D}$ of the constant pressure molar heat capacity as a function of temperature, enthalpies and entropies at $298.15 \mathrm{~K}$, as well as enthalpies and entropies of phase transformation.

\begin{tabular}{lccccrr}
\hline Temperature & $\mathrm{H}^{\circ}{ }_{29.15 \mathrm{~K}}$ or & \multicolumn{2}{c}{$\mathrm{S}^{\circ}{ }_{298.15 \mathrm{~K}}$ or } & \multicolumn{3}{c}{$\mathrm{c}_{\mathrm{p}}{ }^{\circ}=\mathrm{A}+\mathrm{Bx} 10^{-3} \mathrm{~T}+\mathrm{Cx} 10^{5} \mathrm{~T}^{-2}+\mathrm{Dx} 10^{-6} \mathrm{~T}^{2}\left(\mathrm{cal}^{-1} \mathrm{~mol}^{-1} \mathrm{~K}^{-1}\right)$} \\
Interval $(\mathrm{K})$ & $\Delta \mathrm{H}_{\text {transform }}$ kcal.mol ${ }^{-1} \mathrm{~K}^{-1}$ & $\Delta \mathrm{S}_{\text {transform. calmol }}$ & $\mathrm{A}$ & $\mathrm{B}$ & $\mathrm{C}$ & $\mathrm{D}$ \\
\hline $298.15-545$ & -566.424 & 46.311 & 34.206 & 14.942 & -0.948 & 0.254 \\
$545-600$ & 2.16 & 3.966 & 35.450 & 11.1 & 2.232 & -0.508 \\
$600-720$ & 0 & 9 & 34.841 & 11.902 & 2.232 & -0.508 \\
$720-999$ & 0.022 & 0.031 & 34.327 & 12.969 & 2.224 & -0.995 \\
$999-1071$ & 1.359 & 1.360 & 41.764 & 5.525 & 2.224 & -0.995 \\
$1071-1112$ & 2.480 & 2.314 & 41.422 & 5.525 & 2.224 & -0.995 \\
$1112-1200$ & 0.204 & 0.184 & 42.519 & 4.538 & -2.224 & -0.995 \\
$1200-1685.5$ & 0 & 0 & 44.083 & 2.555 & -1.742 & -0.235 \\
\hline
\end{tabular}

Table 2. Thermodynamic data of the species $\mathrm{Ce}_{0.9} \mathrm{Ca}_{0.1} \mathrm{O}_{1.9}$ : coefficients $\mathrm{A}, \mathrm{B}, \mathrm{C}$ and $\mathrm{D}$ of the constant pressure molar heat capacity as a function of temperature, enthalpies and entropies at $298.15 \mathrm{~K}$, as well as enthalpies and entropies of phase transformation.

\begin{tabular}{|c|c|c|c|c|c|c|}
\hline \multirow{2}{*}{$\begin{array}{l}\text { Temperature } \\
\text { Interval }(\mathrm{K}) \\
\end{array}$} & \multirow{2}{*}{$\begin{array}{c}\mathrm{H}^{\circ}{ }_{298,15 \mathrm{~K}} \text { or } \\
\Delta \mathrm{H}_{\text {transform }} \mathrm{kcal} . \mathrm{mol}^{-1} \mathrm{~K}^{-1}\end{array}$} & \multirow{2}{*}{ 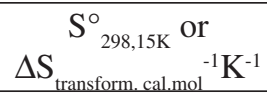 } & \multicolumn{4}{|c|}{$\mathrm{c}_{\mathrm{p}}^{\circ}=\mathrm{A}+\mathrm{Bx} 10^{-3} \mathrm{~T}+\mathrm{Cx} 10^{5} \mathrm{~T}^{-2}+\mathrm{Dx} 10^{-6} \mathrm{~T}^{2}\left(\mathrm{cal} . \mathrm{mol}^{-1} \mathrm{~K}^{-1}\right)$} \\
\hline & & & $\mathrm{A}$ & $\mathrm{B}$ & $\mathrm{C}$ & $\mathrm{D}$ \\
\hline 298.15-600 & -250.359 & 14.957 & 13.241 & 3.915 & -0.641 & 0.401 \\
\hline $600-720$ & 0 & 0 & 12.952 & 4.398 & -0.641 & -0.381 \\
\hline $720-999$ & 0.022 & 0.031 & 12.438 & 5.465 & -0.649 & -0.087 \\
\hline $999-1071$ & 0.644 & 0.644 & 15.961 & 1.939 & -0.649 & -0.087 \\
\hline $1071-1112$ & 1.175 & 1.096 & 15.961 & 1.939 & -0.649 & -0.087 \\
\hline $1112-1755$ & 0.204 & 0.184 & 17.058 & 0.952 & -0.649 & -0.087 \\
\hline
\end{tabular}

Table 3. Thermodynamic data of the species $\mathrm{Ce}_{0,9} \mathrm{Sr}_{0,1} \mathrm{O}_{1,9}$ : coefficients $\mathrm{A}, \mathrm{B}, \mathrm{C}$ and $\mathrm{D}$ of the constant pressure molar heat capacity as a function of temperature, enthalpies and entropies at $298.15 \mathrm{~K}$, as well as enthalpies and entropies of phase transformation.

\begin{tabular}{lccccrr}
\hline Temperature & $\mathrm{H}^{\circ}{ }_{298,15 \mathrm{~K}}$ or & \multicolumn{2}{c}{$\mathrm{S}^{\circ}{ }_{298,15 \mathrm{~K}}$ or } & \multicolumn{2}{c}{$\mathrm{c}_{\mathrm{p}}{ }^{\circ}=\mathrm{A}+\mathrm{Bx} 10^{-3} \mathrm{~T}+\mathrm{Cx} 10^{5} \mathrm{~T}^{-2}+\mathrm{Dx} 10^{-6} \mathrm{~T}^{2}\left(\mathrm{cal}^{-1} \mathrm{~mol}^{-1} \mathrm{~K}^{-1}\right)$} \\
Interval $(\mathrm{K})$ & $\Delta \mathrm{H}_{\text {transform }} \mathrm{Kcal}^{-1} \mathrm{~mol}^{-1} \mathrm{~K}^{-1}$ & $\Delta \mathrm{S}_{\text {transform. cal.mol }}$ & $\mathrm{A}$ & $\mathrm{B}$ & $\mathrm{C}$ & $\mathrm{D}$ \\
\hline $298.15-600$ & -248.330 & 15.374 & 13.123 & 3.904 & -0.682 & 0.373 \\
$600-820$ & 0 & 0 & 13.223 & 4.388 & -0.682 & 0.548 \\
$820-999$ & 0.020 & 0.024 & 13.433 & 4.478 & -0.649 & -0.087 \\
$999-1050$ & 0.644 & 0.644 & 16.956 & 0.952 & -0.649 & -0.087 \\
$1050-1071$ & 0.178 & 0.169 & 17.143 & 0.952 & -0.649 & -0.087 \\
$1071-1685.5$ & 1.175 & 1.096 & 17.125 & 0.952 & -0.649 & -0.087 \\
\hline
\end{tabular}

and so it plays the role of an electronic conductor decreasing the electrical efficiency of the fuel cell. Therefore, to avoid the ceria decomposition under action of hydrogen gas is an important concern. In view of this fact, the diagrams developed here provide nice picture of the impact the degradation by hydrogen may have on a fuel cell operated with a hydrogen plus carbon monoxide mixture generated by in situ catalytic reforming of a hydrocarbon directly fed into the solid oxide fuel cell.
The decomposition of doped ceria electrolytes by hydrogen gas action during high temperature operation, generating $\mathrm{Ce}_{2} \mathrm{O}_{3}$, which imposes power losses to the fuel cell due to electronic conduction has been observed by Zhou ${ }^{4}$. Likewise, Maffei \& Kuriakose ${ }^{6}$ found degradation of planar solid oxide fuel cell composed by doubly doped ceria (with $\mathrm{Gd}$ and Pr) during tests at $700{ }^{\circ} \mathrm{C}$, using an argon $-4 \%$ hydrogen gas mixture at the anode. Good efficiency of up to $42 \%$ was gotten by Milliken, Guruswamy \& Khandkar ${ }^{7}$ 


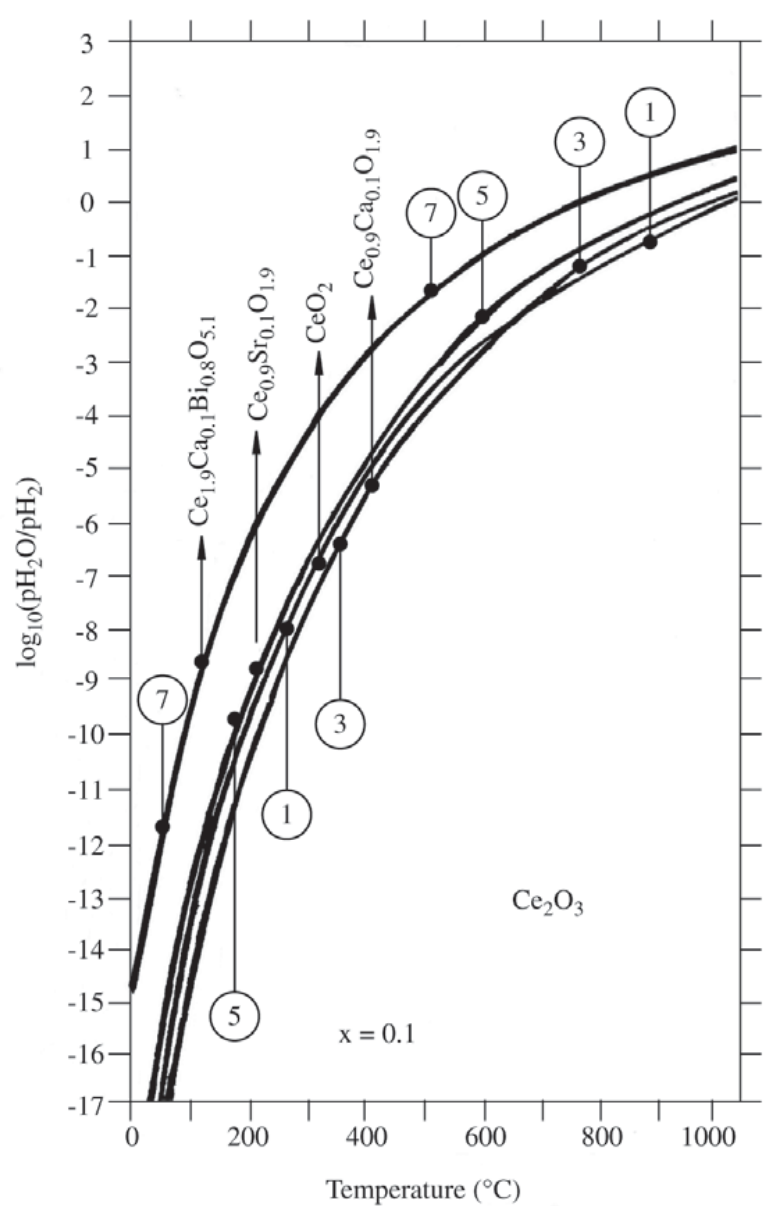

Figure 1. Diagram of $\log _{10}\left(\mathrm{pH}_{2} \mathrm{O} / \mathrm{pH}_{2}\right)$ vs. Temperature $\left({ }^{\circ} \mathrm{C}\right)$ for cerias doped with $\mathrm{Ca}, \mathrm{Sr}$ and $\mathrm{Bi} ; \mathrm{x}=0.1$.

when their fuel cell was operated with humid hydrogen (power densities $>250 \mathrm{~mW} / \mathrm{cm}^{2}$ at $700{ }^{\circ} \mathrm{C}$, with stable performance during $15000 \mathrm{~h}$, in fuel cells of samaria doped ceria electrolyte.

Therefore, the predictions of the diagrams developed here are consistent with experimentally observed facts, thereby constituting a good tool to improve better understanding of the ceria electrolyte stability nearby the anode in the hydrogen fuel cell.

\section{Conclusions}

- The stability domains of cerias doped with calcia, strontia and calcia-bismuth oxide were set up in a diagram of degree of oxidation of the hydrogen fuel gas vs. temperature;

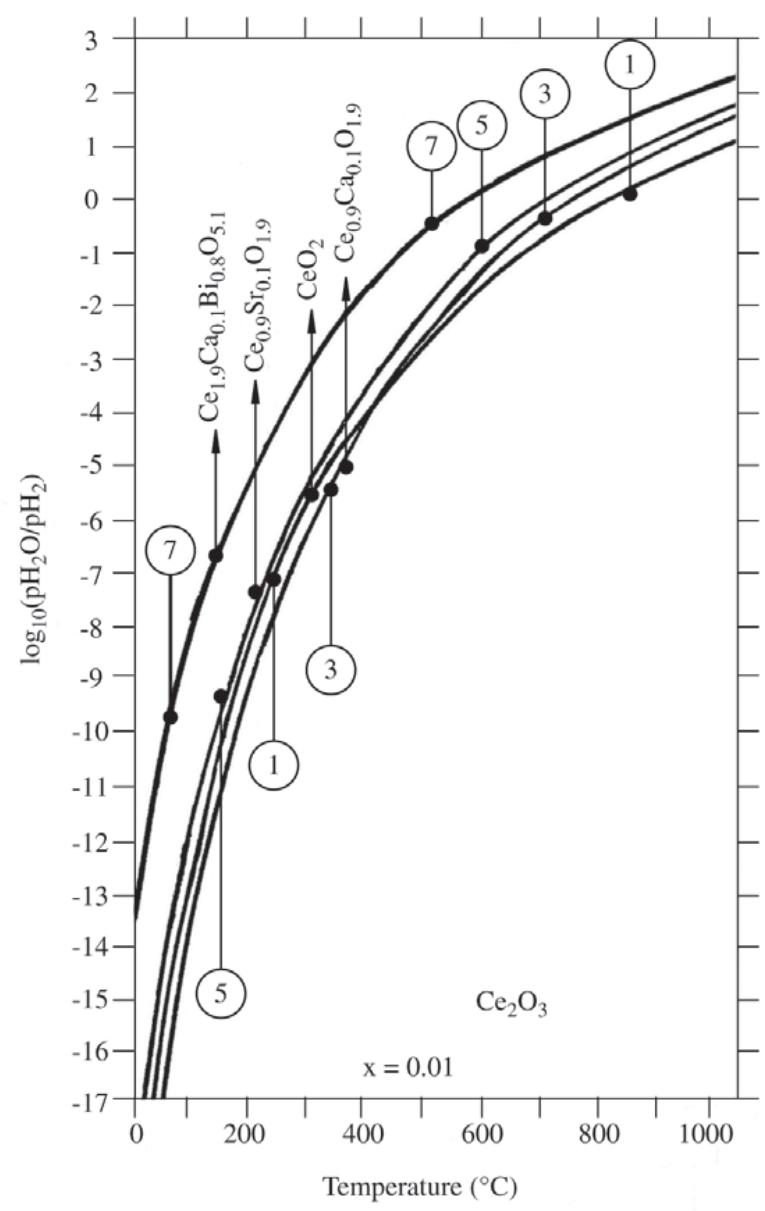

Figure2. Diagram of $\log _{10}\left(\mathrm{pH}_{2} \mathrm{O} / \mathrm{pH}_{2}\right)$ vs. Temperature $\left({ }^{\circ} \mathrm{C}\right)$ for cerias doped with $\mathrm{Ca}, \mathrm{Sr}$ and $\mathrm{Bi} ; \mathrm{x}=0.01$.

- $\mathrm{Ce}_{1.9} \mathrm{Ca}_{0.1} \mathrm{Bi}_{0.8} \mathrm{O}_{5.1}$ and $\mathrm{Ce}_{0.9} \mathrm{Sr}_{0.1} \mathrm{O}_{1.9}$ are less stable than pure ceria for the whole temperature range (from 0 to $1000{ }^{\circ} \mathrm{C}$ );

- $\mathrm{Ce}_{0.9} \mathrm{Ca}_{0.1} \mathrm{O}_{1.9}$ is more stable than pure ceria below about $650{ }^{\circ} \mathrm{C}$ for $\mathrm{x}=0.1$ and below about $400{ }^{\circ} \mathrm{C}$ for $\mathrm{x}=$ 0.01 ;

- At each temperature in the considered range, the pressure ratio $\mathrm{pH}_{2} \mathrm{O}(\mathrm{g}) / \mathrm{pH}_{2}(\mathrm{~g})$ has to be higher than thermodynamically predicted in order to keep $\mathrm{CeO}_{2}$ stable in the electrolyte contacting hydrogen gas.

\section{Acknowledgements}

The authors are grateful to CNPq, CAPES and FAPERJ for the direct and indirect support to this work. 


\section{References}

1. Zhao, H.; Feng, S.H. Hydrothermal Synthesis and Oxygen Ionic Conductivity of Codoped Nanocrystalline Ce ${ }_{x} \mathrm{MBi}_{x} \mathrm{Bi}_{0,4} \mathrm{O}_{2,6-x}, \mathrm{M}=\mathrm{Ca}$, Sr and $\mathrm{Ba}$, Chemistry of Materials 11: (4) p. 958-964, Apr. 1999.

2. Li, G.S.; Mao, Y.C.; Li, L.P.; Feng, S.H.; Wang, M.Q.; Yao, X. Solid solubility and transport properties of nanocrystalline $\left(\mathrm{CeO}_{2}\right)_{(1-x)}\left(\mathrm{BiO}_{1,5}\right)_{x}$ by hydrothermal conditions, Chemistry of Materials 11: (5) p. 1259-1266 May 1999.

3. Doshi, R.; Richards, V.L.; Carter, J.D.; Wang, X.P.; Krumpelt, M., Development of solid-oxide fuel cells that operate at 500 degrees $C$, Journal of The Electrochemical Society 146: (4) p. 1273-1278, Apr. 1999.

4. Zhou, Y. The influence of redox reaction of the sintering of cerium oxide, Journal of Materials Synthesis and Processing 6: (6) p. 411-414 Nov. 1998.

5. Sahibzada, M.; Steele, B.C.H.; Barth, D.; Rudkin, R.A.; Metcalfe, I.S. Fuel 78: (6) p. 639-643 May 1999.

6. Maffei, N.; Kuriakose, A.K. Solid oxide fuel cells of ceria doped with gadolinium and praseodymium, Solid State Ionics 107: (1-2), p. 67-71 Mar. 1998.

7. Milliken, C.; Guruswamy, S.; Khandkar, A. Evaluation of ceria electrolytes in solid oxide fuel cells electric power generation, Journal of th Electrochemical Society 146: (3) p. 872-882 Mar. 1999.

8. Murray, E.P.; Tsai, T.; Barnett, S.A. A direct-methane fuel cell with a ceria-based anode, Nature 400: (6745) p. 649-651 Aug. 12, 1999.

9. Maric, R.; Ohara, S.; Fukui, T.; Inagaki, T.; Fujita, J. High-performance Ni-SDC cermet anode for solid oxide fuel cells at median operating temperature, Electrochemical and Solid State Letters 1: (5) p. 201203 Nov. 1998.

10. Uchida, H.; Osuga, T.; Watanabe, M. High-performance electrode for medium-temperature solid oxide fuel cells - Control of microstructure of ceria-based anodes with highly dispersed ruthenium electrocatalysts, Journal of the Electrochemical Society 146: (5) p. 1677-1682 May 1999.
11. Marina, A.O.; Bagger, C.; Prindahl, S.; Mogensen, M. A solid oxide fuel cell with a gadolinia-doped ceria anode: preparation and performance, Solid State Ionics 123: (1-4) p. 199-208 Aug. 1999.

12. Ishihara, T.; Shibayama, T.; Nishiguchi, H.; Takita, Y. Nickel-Gd-doped $\mathrm{CeO}_{2}$ cermet anode for intermediate temperature operating solid oxide fuel cells using $\mathrm{LaGaO}_{3}$-based perovskite electrolyte, Solid State Ionics 132: (3-4) p. 209-216 Jul. 2000.

13. Uchida, H.; Suzuki, H.; Watanabe, M. High-performance electrode for medium-temperature solid oxide fuel cells - Effects of composition and microstructures on performance of ceria-based anodes, Journal of the Electrochemical Society 145: (2) p. 615-620, Feb. 1998.

14. Antonucci, V.; Modica, E.; Monforte, G.; Arico, A.S.; Antonucci, P.L. Ageing effects of electrodes in ceramic fuel cells, Journal of the European Ceramic Society 18: (2) p. 113-122, 1998.

15. Malta, L.F. B.; Ogasawara, T. Synthesis of Doped Ceria Solid Electrolyte: Bibliographic Revue, Proceedings of the $45^{\text {th }}$ Brazilian Ceramic Congress, , Florianópolis-SC, Brazilian Ceramic Association, São Paulo-SP, Brazil, CDROM, p. 0301101-0301112,May30-June2, 2001.

16. Malta, L.F.B. Malta; Ogasawara, T.; Medeiros, M.E. Study of the Crystallization Process of Cerium Dioxide under Mild Hydrothermal Conditions by Using XRD, Proceedings of the IV Technical Meeting on Materials and Chemistry (IV ETMQ), IPqM/Naval Ministry, Rio de Janeiro-RJ, Brazil, p. 12-14, 6pp, November 2001.

17. Malta, L.F.B. Malta; Caffarena, V.R.; Medeiros, M.E.; Ogasawara, T. Thermodifferential Analysis of the nonstoichiometric ceria sample obtained via Hydrothermal Synthesis, Proceedings of the III Cebratec, Poços de Caldas-MG, Brazil, 4pp, 08/04/2002-10/04/2002.

18. Malta, L.F. B. Synthesis and Characterization of Cerias Doped with $\mathrm{Ca}$ and $\mathrm{Sr}$ and Codoped with $\mathrm{Ca}$-Sr for Solid Electrolyte Fuel Cells, M.Sc. Thesis, Metallurgical and Material Engineering Department, COPPE/ UFRJ, xvii + 105p, concluded in 29/05/2002 . 